\title{
Profitability of important summer vegetables in Keranigonj upazilla of Bangladesh
}

\author{
M. R. Hasan ${ }^{1^{*}}$, Dr. HU Bai ${ }^{2}$ and M. A. Islam ${ }^{3}$ \\ ${ }^{1}$ Department of Agribusiness and Marketing, Sher-e-Bangla Agricultural University, Dhaka, Bangladesh; Department \\ of Resource and Environmental Policy, Ehime University, Japan and ${ }^{3}$ Agricultural Economics Division , Bangladesh \\ Rice Research Institute, Gazipur, Bangladesh, *E-mail: rashidul_prince@yahoo.com
}

\begin{abstract}
The study was conducted in Keranigonj upazilla under Dhaka district from the month of April to May in 2014 to determine the cost and return of some important vegetables namely bottle gourd, brinjal and cucumber. Data were collected from 20 bottle gourd farmers, 30 brinjal farmers and 20 cucumber farmers by using purposive sampling method. The averages total cost per hectare were calculated at Tk. 4,12,713, Tk. 2,69,627 and Tk.2,56,258 for bottle gourd, brinjal and cucumber production.Net return per hectare was the highest for brinjal $($ Tk. $7,32,811)$ and the lowest for bottle gourd (Tk. 5,79,431). The benefit cost ratios (BCR) considering variable cost were 2.83 , 4.88 and 4.57 for bottle gourd, brinjal and cucumber respectively. The highest BCR was for brinjal (3.72) and the lowest for bottle gourd (2.40) on the basis of total cost. Lack of capital, low price of vegetables, high price of input, price fluctuation, disease, unavailability of input and lack of storage facilities were the major problems of farmers.
\end{abstract}

Keywords: Vegetables, Cost, Returns, Profitability, Benefit cost ratio (BCR), Important vegetables

\section{Introduction}

Food and nutrition are the crucial problem for Bangladesh. The majority of people are suffering from malnutrition. This could be partly compensated through consumption of adequate amount of fresh vegetables because vegetables are important sources of vitamin and minerals. An adult should consume at least $280 \mathrm{~g}$ vegetables per day (Ramphal and Gill, 1990). But a Bangladeshi is taking only $70-75 \mathrm{~g}$ per day from its annual production of 2.50-3.00 million tons against the requirement of 9.50-10.00 million tons (Hossain, 1999). More vegetable production will effectively help to improve the problems of existing acute malnutrition and food shortage. The area under vegetable farming increased from 1,71,830 ha to about 470414 ha from the year 1990 to the year 2010. Likewise, the production of vegetable also increased from about 7,57,415 metric tons to about 15,93,681 metric tons during that period (BBS, 2010). The major winter vegetables are cabbage, cauliflower, tomato, brinjal, radish, hyacinth bean, bottle gourd etc. On the other hand, pumpkin, bitter gourd, teasle gourd, ribbed gourd, ash gourd, okra, yard long bean and indian spinach are the major summer vegetables. Various types of vegetables are growing on commercial basis either under contract farming or under individual management in different parts of the country. Some of these vegetables are exported to foreign countries through exporters, among them BRAC initiative for vegetables export is appreciable. Dhaka city is over populated and a remarkable portion of vegetables are supplied from Keranigonj upazilla. Few economic studies were done with some vegetables( Monayem et al., 1998, Mamun et al., 2010; Khan et al., 2009 and Yusuf et al., 2008) but no study emphasized the economics of commercial vegetables in the present study area of Bangladesh. Moreover the previous studies were done in different regions of Bangladesh. But the present study focuses major summer vegetables and selects the location near Dhaka city. Dhaka is the capital of Bangladesh and more than one crore people lived in Dhaka city. A large portion of vegetables are supplied to Dhaka from this area. So it is important and justified to analyze the cost and return of summer vegetables production near Dhaka city. Therefore the present study was designed to analyze the profitability of some commercial summer vegetables. The specific objectives of the study were:

i) To estimate the production cost and profit of vegetables producer.

ii) To identify the major problems and constraints of vegetables production. 


\section{Materials and Methods}

The study was conducted in Jogonnathpur village under Keranigonj upazilla of Dhaka district. In this study we use purposive sampling technique. Total twenty bottle gourd farmers, thirty brinjal farmers and twenty cucumber farmers were selected for this study. Primary data were collected for this study. Tabular and simple statistical methods were used to analyze the collected data. Data were collected from April to May, 2014 by using a pre-tested interview schedule. Interest rate was assumed to be $12.00 \%$. The vegetable season was considered for four month. The collected data were analyzed as per objective of the study. The following formulas were used to estimate cost and return for different vegetables:

Total variable cost $=$ Seed and seedling cost + Power tiller cost + Hired labor cost + Fertilizer cost + Pesticide and insecticide cost+ Irrigation cost+ Bamboo cost.

Total cost= Family labor cost + Total variable cost + Interest on operating capital+ Land use cost. Gross Margin= Total return- Total variable cost

Net Margin= Total return- Total cost

Benefit cost ratio (Variable cost basis) $=\frac{\text { Total return }}{\text { Total variable cost }}$

Benefit cost ratio $($ Total cost basis $)=\frac{\text { Total return }}{\text { Total cost }}$

\section{Results and Discussion}

\section{Socioeconomic characteristics of the vegetables farmers}

Table 1 summarizes the socioeconomic profile of sample vegetable farmers. $35.00 \%$ of the bottle gourd farmers belong to the age group $31-40$ years. $46.67 \%$ of the brinjal producing farmers belongs to the same age group. $55.00 \%$ of the cucumber farmers belong to the age group $41-50$ years. It is rare that age group 61 to above farmers produce vegetables. It is also found from the study that the occupation of the most farmers was agriculture and they depend fully on agriculture. It is also evident from the table that most of vegetable farmer's educations were primary and secondary level. Only few farmers were higher secondary or graduate level. It is also evident from the table that most of the vegetable farmers had ten years of vegetable production experience. This fact therefore implies that farmer's profit from the vegetable production may mainly result their repeatedly production activities or experiences.

\section{Cost and return of bottle gourd production}

There are different types of cost related with bottle gourd production. These are seed or seedling, power tiller, human labor, fertilizer, pesticide and insecticide, irrigation and bamboo cost. Farmers were generally used different types of pesticide and insecticide. Among them karatop, sevin, aerostar, bectin, marshal, furadon and ripcord were popular. Human labor cost and bamboo cost were the important production cost for bottle gourd (Table 2). Among different costs items, human labor cost was higher $(30 \%)$ which was followed by bamboo cost $(20.84 \%)$ and insecticide cost $(17.62 \%)$ respectively. In the study area, total variable cost per hectare for bottle gourd production was Tk. 3,50,541. Interests on operating capital for four month were Tk. 7,011.Land use cost per hectare was Tk. 26,212 which was $6.35 \%$ of total cost. It is found that total cost per hectare for bottle gourd production was Tk. 4,12,713.It is evident from the table that total number of bottle gourd production per hectare was 42,040. Total return per hectare was Tk. $9,92,144$. It is also evident that gross margin and net margin per hectare were Tk. 6,41,603 and Tk.5,79,431 respectively. The net margin per hectare of bottle gourd production indicates that bottle gourd farmers earns considerable amount of profit. Benefit cost ratio on the basis of variable cost was 2.83 and total cost basis was 2.40 which ensure farmers considerable amount of return from their investment. The study revealed that the cultivation of bottle gourd at farm level was profitable to the farmers. 
Hasan et al.

Table 1. Socio economic profile of vegetable farmers

\begin{tabular}{|c|c|c|c|c|c|c|}
\hline \multirow[t]{2}{*}{ Particulars } & \multicolumn{2}{|c|}{ Bottle gourd } & \multicolumn{2}{|c|}{ Brinjal } & \multicolumn{2}{|c|}{ Cucumber } \\
\hline & No $(n=20)$ & Percent & No $(n=30)$ & Percent & No $(n=20)$ & Percent \\
\hline \multicolumn{7}{|c|}{ Age group (years) } \\
\hline $20-30$ & 3 & 15.00 & 1 & 3.33 & 2 & 10.00 \\
\hline $31-40$ & 7 & 35.00 & 14 & 46.67 & 6 & 30.00 \\
\hline $41-50$ & 4 & 20.00 & 11 & 36.67 & 11 & 55.00 \\
\hline $51-60$ & 5 & 25.00 & 4 & 13.33 & 1 & 5.00 \\
\hline $61-70$ & 1 & 5.00 & - & - & - & - \\
\hline \multicolumn{7}{|c|}{ Occupation } \\
\hline Agriculture & 19 & 95.00 & 28 & 93.33 & 20 & 100.00 \\
\hline Business & - & - & - & - & - & - \\
\hline Others & 1 & 5.00 & 2 & 6.67 & - & - \\
\hline \multicolumn{7}{|c|}{ Level of education } \\
\hline Illiterate & - & - & 1 & 3.33 & 2 & 10.00 \\
\hline Primary & 8 & 40.00 & 16 & 53.34 & 10 & 50.00 \\
\hline Secondary & 10 & 50.00 & 12 & 40.00 & 8 & 40.00 \\
\hline $\begin{array}{l}\text { Higher } \\
\text { Secondary }\end{array}$ & 2 & 10.00 & 1 & 3.33 & - & - \\
\hline Graduate & - & - & - & - & - & - \\
\hline \multicolumn{7}{|c|}{ Experience in vegetables production } \\
\hline $0-5$ & 5 & 25.00 & 2 & 6.67 & 3 & 15.00 \\
\hline $5-10$ & 10 & 50.00 & 18 & 60.00 & 12 & 60.00 \\
\hline 10- Above & 5 & 25.00 & 10 & 33.33 & 5 & 25.00 \\
\hline
\end{tabular}

Table 2. Cost and return per hectare of Bottle gourd production

\begin{tabular}{|c|c|c|c|}
\hline \multicolumn{4}{|c|}{ Bottle gourd cost and return } \\
\hline Particulars & Unit price (Tk./kg) & Total amount $(\mathrm{kg})$ & Total Taka \\
\hline Seed/seedling cost (Tk/ha) & & & $22,775(5.51 \%)$ \\
\hline Power tiller cost (Tk/ha) & & & 12,629 \\
\hline Human labor cost (Tk/ha) & & & $1,24,710(30 \%)$ \\
\hline Family labor & 300 & 96.50 & 28,950 \\
\hline Hired labor & 300 & 319.20 & 95,760 \\
\hline Fertilizer cost (Tk/ha) & & & $38,837(9.41 \%)$ \\
\hline Urea & 16 & 1044.10 & 16,706 \\
\hline TSP & 22 & 546.10 & 12,014 \\
\hline DAP & 30 & 211.80 & 6,354 \\
\hline MP & 15 & 175.90 & 2,639 \\
\hline ZnSo4 & 150 & 7.50 & 1,125 \\
\hline Pesticide/Insecticide cost(Tk/ha) & & & $72,754(17.62 \%)$ \\
\hline Irrigation cost (Tk/ha) & & & $21,758(5.27 \%)$ \\
\hline Bamboo cost (Tk/ha) & & & $86,028(20.84 \%)$ \\
\hline TVC (Tk/ha) & & & $3,50,541(84.93 \%)$ \\
\hline $\begin{array}{l}\text { Interest on operating capital for four } \\
\text { months (Tk/ha) }\end{array}$ & & & 7,011 \\
\hline Land use cost (Tk/ha/season) & & & $26,212(6.35 \%)$ \\
\hline $\mathrm{TC}(\mathrm{Tk} / \mathrm{ha})$ & & & $4,12,713(100 \%)$ \\
\hline Total production number (no./ha) & & 42,040 & \\
\hline Price per bottle gourd & 23.60 & & \\
\hline Total Return (Tk/ha) & & & $9,92,144$ \\
\hline $\mathrm{GM}(\mathrm{Tk} / \mathrm{ha})$ & & & $6,41,603$ \\
\hline NR (Tk/ha) & & & $5,79,431$ \\
\hline BCR (Variable cost basis) & & & 2.83 \\
\hline BCR (Total cost basis) & & & 2.40 \\
\hline
\end{tabular}




\section{Cost and return of Brinjal production}

Human labor cost is very important for producing brinjal (Table 3). Total cost per hectare for family and hired labor were Tk. 36,300 and Tk. 71,100 respectively. Farmers generally depend on hired labor. During the vegetables production season labor crisis is a common phenomenon. Farmer generally used power tiller for cultivating their land. It is found from the study that total cost per hectare for power tiller was Tk. 25,013. It is also evident from the table that per hectare seed and seedling cost was Tk. 25,013. Farmers are now used hybrid seed for their field. Farmer used different types of fertilizer, among them Urea, TSP, MP and $\mathrm{ZnSO}_{4}$ were popular. Total cost per hectare for fertilizer was Tk. 28,842 which was $10.69 \%$ of the total cost. Pesticide and insecticide cost was Tk. 45,144 and irrigation cost was Tk. 21,026. Total variable cost per hectare for producing brinjal was Tk. 2,05,439. Total interest on operating capital for a vegetable season was Tk. 4,109 and land use cost was Tk. 23,779. It is evident from the table that total cost per hectare for producing brinjal was Tk. 2,69,627. From the basis of farmer's data total production per hectare of brinjal was $55,691 \mathrm{~kg}$. The average price for per $\mathrm{kg}$ brinjal was Tk. 18.00. It is interesting that farmers get higher price for their brinjal, if farmer harvest early in the season and farmers get lower price for their brinjal for pick season. It is found from the study that farmer's average total return was Tk. 10,02,438. Gross margin and net return per hectare were Tk. 7,96,999 and Tk. 7,32,811 respectively. Benefit cost ratio on the basis of variable cost and total cost basis were 4.88 and 3.72 respectively. The BCR over variable cost and total cost implies that brinjal production at the study area was highly profitable. The impressive BCR of brinjal cultivation keeps farmers interest to produce more brinjal to the study area. But sometimes brinjal was severely affected by disease and pest which frustrate the farmers.

Table 3. Cost and return per hectare of Brinjal production

\begin{tabular}{|c|c|c|c|}
\hline \multicolumn{4}{|c|}{ Brinjal cost and return } \\
\hline Particulars & $\begin{array}{l}\text { Unit price } \\
(\mathrm{Tk} / \mathrm{kg})\end{array}$ & Total amount(kg) & Total Taka \\
\hline Seed/seedling cost (Tk/ha) & & & $25,013(9.27 \%)$ \\
\hline Power tiller cost (Tk/ha) & & & 14,314 \\
\hline Human labor cost (Tk/ha) & & & $1,07,400(39.83 \%)$ \\
\hline Family labor & 300 & 121 & 36,300 \\
\hline Hired labor & 300 & 237 & 71,100 \\
\hline Fertilizer cost (Tk/ha) & & & $28,842(10.69 \%)$ \\
\hline Urea & 16 & 871 & 13,936 \\
\hline TSP & 22 & 443 & 9,746 \\
\hline MP & 15 & 274 & 4,110 \\
\hline ZnSo4 & 150 & 7 & 1,050 \\
\hline Pesticide/Insecticide cost(Tk/ha) & & & $45,144(16.74 \%)$ \\
\hline Irrigation cost (Tk/ha) & & & $21,026(7.79 \%)$ \\
\hline TVC (Tk/ha) & & & $2,05,439(76.19 \%)$ \\
\hline $\begin{array}{l}\text { Interest on operating capital for four months } \\
\text { (Tk/ha) }\end{array}$ & & & 4,109 \\
\hline Land use cost (Tk/ha/season) & & & $23,779(8.81 \%)$ \\
\hline TC (Tk/ha) & & & $2,69,627(100 \%)$ \\
\hline Total production (kg/ha) & & 55691 & \\
\hline Price per $\mathrm{kg}$ & 18 & & \\
\hline Total Return (Tk/ha) & & & $10,02,438$ \\
\hline GM(Tk/ha) & & & $7,96,999$ \\
\hline NR (Tk/ha) & & & $7,32,811$ \\
\hline BCR (Variable cost basis) & & & 4.88 \\
\hline BCR (Total cost basis) & & & 3.72 \\
\hline
\end{tabular}




\section{Cost and return of Cucumber production}

There are different variable cost items included for cucumber production (Table 4). These are seed and seedling, power tiller, hired labor, fertilizer, pesticide and insecticide and irrigation cost. Total fixed cost includes total variable cost, interest on operating capital for a season and land use cost. It is evident from the table that seed and seedling cost, power tiller cost, human labor cost, fertilizer cost,pesticides and insecticide cost and irrigation cost were Tk. 16,998.74, Tk. 13,182.39, Tk.1,07,127, Tk. 20,735.78, Tk. $56,083.5$ and Tk. $18,792.66$ respectively. It is evident from the table that total variable cost per hectare for cucumber production was Tk. 2,05,590.10 which covered $80 \%$ of total cost. Interest on operating capital and land use cost for a season were Tk. 4,112 and Tk. 19,226.19 respectively. It is found from the study that total cost per hectare for producing cucumber was Tk. 2,56,258 which mean that cucumber production was expensive. Total production per hectare was $40,778.44 \mathrm{~kg}$ and average price of cucumber was Tk. 23.05. It is evident from the table that total return, gross margin and net return per hectare were Tk. 9,39,943, Tk. 7,34,353 and Tk. 6,83,685 respectively which ensure that farmers get considerable amount of return from their investment. Benefit cost ratio on the basis of variable cost and total cost basis were 4.57 and 2.87 respectively. The study revealed that BCR was so attractive because of higher production and higher price. Farmers were produce cucumber because they have previous experience and they build a strong network to the metropolitan city vegetable wholesaler.

Table 4. Cost and return per hectare of Cucumber production

\begin{tabular}{|c|c|c|c|}
\hline \multicolumn{4}{|c|}{ Cucumber cost and return } \\
\hline Particulars & Unit price $(\mathrm{Tk} / \mathrm{kg})$ & Total amount $(\mathrm{kg})$ & Total Taka \\
\hline Seed/seedling cost (Tk/ha) & & & $16,998.74(6.63 \%)$ \\
\hline Power tiller cost (Tk/ha) & & & $13,182.39$ \\
\hline Human labor cost (Tk/ha) & & & $1,07,127(41.80 \%)$ \\
\hline Family labor & 300 & 91.10 & 27,330 \\
\hline Hired labor & 300 & 265.99 & 79,797 \\
\hline Fertilizer cost $(\mathrm{Tk} / \mathrm{ha})$ & & & $20,735.78(8.09 \%)$ \\
\hline Urea & 16 & 533.28 & $8,532.48$ \\
\hline TSP & 22 & 422.15 & $9,287.3$ \\
\hline MP & 15 & 194.40 & 2,916 \\
\hline Pesticide/Insecticide cost(Tk/ha) & & & $56,083.5(21.88 \%)$ \\
\hline Irrigation cost (Tk/ha) & & & $18,792.66(7.33 \%)$ \\
\hline TVC (Tk/ha) & & & $2,05,590.1(80.22 \%)$ \\
\hline $\begin{array}{l}\text { Interest on operating capital for months } \\
(\mathrm{Tk} / \mathrm{ha})\end{array}$ & & & 4,112 \\
\hline Land use cost (Tk/ha/season) & & & $19,226.19(7.50 \%)$ \\
\hline TC (Tk/ha) & & & $2,56,258(100 \%)$ \\
\hline Total production $(\mathrm{kg} / \mathrm{ha})$ & & 40778.44 & \\
\hline Price per kg & 23.05 & & \\
\hline Total Return (Tk/ha) & & & $9,39,943$ \\
\hline $\mathrm{GM}(\mathrm{Tk} / \mathrm{ha})$ & & & $7,34,353$ \\
\hline NR (Tk/ha) & & & $6,83,685$ \\
\hline BCR (Variable cost basis) & & & 4.57 \\
\hline BCR (Total cost basis) & & & 2.87 \\
\hline
\end{tabular}

\section{Compare the financial profitability of different vegetables production in different region in Bangladesh}

Several studies were done to estimate the financial profitability of different vegetables production (Table 5). It is evident from the table that productions of different vegetables were increased chronologically. This is due to adoption of farmers for different HYV varieties of vegetables. Price of different vegetables was also increased through time change. Farmers were adjusted their vegetables price due to change the production cost. Now farmers used different insecticide, pesticide and fertilizer to increase production and protect vegetables from disease and pest. Now-a-days farmers try to minimized 
wastage of vegetables. For this reason profitability of different vegetables also increased. It is true that total production cost of different vegetables increased but net margin also increased. Farmers were produce different vegetables because vegetables productions were profitable in the present study area which is reflected by high BCR for different vegetables. The previous studies were done several years ago and we can interpret the different return by yield, price and place difference. The study area is near to Dhaka. Farmers can easily transport their vegetables to Dhaka city and get higher prices for their vegetables. The prices of vegetables are high in Dhaka because of high average income. Finally it is clear that productions of vegetables are more profitable in the study area than other area.

Table 5. Compare the financial profitability of different vegetables production in different region

\begin{tabular}{|c|c|c|c|c|c|c|c|c|}
\hline $\begin{array}{c}\text { Cultivation } \\
\text { year }\end{array}$ & Study Area & $\begin{array}{l}\text { Yield } \\
\text { (kg/ha) }\end{array}$ & $\begin{array}{l}\text { Price } \\
(\mathrm{Tk} / \mathrm{kg})\end{array}$ & $\begin{array}{l}\text { Gross } \\
\text { Return } \\
(\mathrm{Tk} / \mathrm{ha})\end{array}$ & $\begin{array}{c}\text { Total } \\
\text { Cost } \\
\text { (Tk/ha) }\end{array}$ & $\begin{array}{c}\text { Net } \\
\text { return } \\
(\mathrm{Tk} / \mathrm{ha})\end{array}$ & BCR & Sources \\
\hline \multicolumn{9}{|l|}{ Bottle gourd } \\
\hline 1998 & Norsingdi & 9,560 no. & 6.12 & 58,480 & 43,614 & 14,866 & 1.34 & Mawla, 1998 \\
\hline 2009 & Mymensingh & 10,000 no. & 20.00 & $2,00,000$ & $1,05,344$ & 94,656 & 1.90 & Khayer, 2009 \\
\hline 2014 & Dhaka & 42,040 no. & 23.60 & $9,92,144$ & $4,12,713$ & $5,79,431$ & 2.40 & Present study \\
\hline \multicolumn{9}{|l|}{ Brinjal } \\
\hline 1997 & Bangladesh & 11,730 & 6.00 & 70,372 & 17,343 & 53,029 & 4.06 & EPC, 1997 \\
\hline 1998 & Comilla & 24,699 & 2.51 & 61,994 & 31,339 & 30,655 & 1.98 & Miah et al., 1998 \\
\hline 2002 & Jessore & 43,899 & 7.09 & $3,10,293$ & $1,77,457$ & $1,32,836$ & 1.75 & Rashid et al. 2002 \\
\hline 2014 & Dhaka & 55,691 & 18.00 & $10,02,438$ & $2,69,627$ & $7,32,811$ & 3.72 & Present study \\
\hline \multicolumn{9}{|l|}{ Cucumber } \\
\hline 2008 & Mymensingh & $24,583.33$ & 10 & $2,45,833$ & $1,00,677$ & $1,45,156$ & 2.44 & Saiful, 2008 \\
\hline 2014 & Dhaka & $40,778.44$ & 23.05 & $9,39,943$ & $2,56,258$ & $6,83,685$ & 2.87 & Present study \\
\hline
\end{tabular}

\section{Problems and possible solutions for vegetables production}

There are many problems faced by the farmers for producing vegetables (Table 6). It is common that farmer get higher price of their vegetables if they harvest early. It may be opposite if the farmers harvest their vegetables during the pick season. Most of the bottle gourd farmers faced the problems of price fluctuation and disease. Farmers were also faced the problem of high price of input and lack of storage facilities. One of the important problems of brinjal production was the disease. Brinjal producing farmers also faced the capital shortage, storage facilities and price fluctuation problem. Capital shortage and price fluctuation problems were the major crucial problems for cucumber producer which account for $75.00 \%$. High price of input and disease problems are also important for cucumber producer. The vegetables farmers also suggest different solutions to overcome their problems. They need regular government extension service. Farmers also suggest that government agricultural bank must give capital without any bribe and minimize hassle. Farmers also suggest that false fertilizer damage their vegetables. Government must ensure punishment for false fertilizer business dealers and retailers. The farmers also believe that governmental vegetables storage facilities must introduce for the ensuring the availability and food security for the mass people of the country. 
Table 6. Problems for vegetables production

\begin{tabular}{|l|c|c|c|c|c|c|}
\hline \multirow{2}{*}{ Problems } & \multicolumn{2}{|c|}{ Bottle gourd } & \multicolumn{2}{c|}{ Brinjal } & \multicolumn{2}{c|}{ Cucumber } \\
\cline { 2 - 7 } & $\begin{array}{c}\text { No. of respondent } \\
(\mathrm{n}=20)\end{array}$ & Percent & $\begin{array}{c}\text { No. of respondent } \\
(\mathrm{n}=30)\end{array}$ & Percent & $\begin{array}{c}\text { No. of respondent } \\
(\mathrm{n}=20)\end{array}$ & $\begin{array}{c}\text { Percent } \\
\text { Lack of capital }\end{array}$ \\
\hline Low price of vegetables & 12 & 30.00 & 23 & 76.66 & 15 & 75.00 \\
\hline High price of input & 13 & 60.00 & 17 & 56.66 & 10 & 50.00 \\
\hline Price fluctuation & 18 & 95.00 & 16 & 53.66 & 14 & 70.00 \\
\hline $\begin{array}{l}\text { Vegetables are affected } \\
\text { by disease }\end{array}$ & 18 & 90.00 & 23 & 76.66 & 15 & 75.00 \\
\hline Unavailability of input & 6 & 29 & 96.66 & 14 & 70.00 \\
\hline Lack of storage facilities & 10 & 50.00 & 23 & 76.66 & 11 & 55.00 \\
\hline
\end{tabular}

\section{Conclusion and policy implication}

The study estimates the profitability of different vegetables. It can be concluded from the study that the sample farmers found vegetables production were profitable in the study area though it has some constraints. Among the three vegetables brinjal production was more profitable though brinjal was severely affected by insect and disease. Price fluctuation is a common problem for vegetables production. It is found from the study that BCR were high for different vegetables. So it is important to encourage the farmers to produce more vegetables in the study area. Proper measures should be taken to ensure adequate and timely availability of various production inputs such as seeds, fertilizers and insecticides. Government should take initiative to encourage farmers to produce more vegetables. In addition government should ensure free transportation of vegetables load vehicles and established cold storage for producer and consumer benefit. It is important that the sample size is small for present study. So further study is needed in this area and the policy maker should carefully interpret the result of the present study.

On the basis of the above discussion, the following recommendation would be followed for efficient vegetable production.

- According to the farmer's opinion, the price of vegetable is very low at peak harvesting period. Establishment of cold storage will ensure fair price for the farmers.

- Insecticide and pesticide may harm farmer's body skin. Sometimes farmers spray the insecticide and pesticide and bring the vegetable to the market in the same day. It may create serious health problem to the consumer. Government extension service must be strengthening their activities to avoid this problem.

- Government must monitor the market to take action against false fertilizer. Sometimes farmers need cash support from the government. Government can encourage vegetable production by giving incentives which will increase vegetable production and ensure food security of the country.

\section{References}

Ali, M.Y., Ahmed, M.M. and Islam, M.B. 2008.Homestead vegetable gardening: meeting the need of year round vegetable requirement of farm family. On farm Research Division, Bangladesh Agricultural Research Institute, Gazipur-1701, Bangladesh.

Bangladesh Bureau of Statistics.2010. Statistical Year Book of Bangladesh, Ministry of planning, Government of Peoples Republic of Bangladesh, Dhaka.

EPC.1997. FAO. Horticulture baseline production and marketing survey, Vol.III. Annexure (part 1), Engineering and Planning Consultants Ltd., 43 Dilkusha C/A, Dhaka-1000.

Hossain, S.M.M. 1999. Research progress and programme on improvement of vegetables at BARI. Proceeding of a workshop on vegetable research and development in Bangladesh held during 28-29 January, 1999, Dhaka, Bangladesh.

Saiful, M.S. 2008. An economic analysis of cucumber cultivation in Mymensingh district. M.S. Thesis, Department of Agricultural Economics, BAU, Mymensingh. 
Khan, M.H.A., Ali, M.Y., Quayyum, M.A., Nazrul, M.I. and Hossain, M.J. 2009. Year round homestead vegetable production: A means of reducing poverty and nutritional deficiency for small farm, Bangladesh J. Agril. Res. 34(1):169-174.

Khayer. U.2009. Comparative economic analysis of bean and bottle gourd production in some selected areas of Mymensingh district, MS Thesis, Department of Agricultural Economics, BAU, Mymensingh.

Mamun, M.H.A., Bashar H.M.K, Islam, M.S., Howlader, M.H.K. andHasan M.S. 2010. A case study on homestead vegetables cultivation: food security and income, Int. J. Sustain. Crop Prod. 5(1), 5-10.

Monayem, M.A., Rahman, A.K.M.M., Haque, A.K.M.H. andJabbar, M.A. 1998. Economics of some winter vegetables production and their farm level marketing in five villages of Comilla District, Research report, Agricultural Economics Division, BARI, Joydebpur, Gazipur.

Miah, M A M., Rahman, A.K.M,M.,Haque, A KMH and Jabbar, M.A. 1998. Economics of some winter vegetables production and their farm level marketing in five villages of Comilla district. Bangladesh J. Agril. Res.23(2):361-376.

Mowla, M.G. 1998. An economic analysis of some selected winter vegetables in a selected area of Norsingdi District, M.S. Thesis, Department of Agricultural Economics, BAU, Mymensingh.

Rampal and Gill, H.S. 1990. Demand and supply of vegetables and pulses in South Asia, Proceedings of a workshop held at Islamabad, Pakistan, 24-29 September. AVRDC Publication No. 90-331, Tainan, Taiwan.

Rashid, M.A.,Rouf, F.M.A. and Alam, S.N. 2002. Economics of brinjal cultivation at Jessore region in Bangladesh. Economic Affairs, 47(Qr.4): 215-221. 